\title{
Research on the Cultivation of Innovative Entrepreneurship Ability of Business English majors under the Background of Internet
}

\author{
Xiaoxia Yin ${ }^{1}$ \\ ${ }^{1}$ JiangXi Tourism \& Commerce Vocational college Nanchang, Jiangxi, 330100, China
}

\begin{abstract}
With the development of social economy and Internet technology, the demand for business English professionals has improved significantly. Business English major is mainly to train applied high-quality technical talents for the society, so we should pay attention to the practical ability of the students. Under the background of the era of "Internet ", business English education should pay attention to the cultivation of students' innovative and entrepreneurial ability, and explore more ways to cultivate the ability of combining innovative entrepreneurial practice with business English teaching.
\end{abstract}

\section{Introduction}

With the rapid development of social economy and the development of economic globalization, China's foreign trade economy is also developing, foreign trade volume is increasing year by year, and the cultivation of business English talents in colleges and universities also shows great potential and development space. In the training of students majoring in business English, colleges and universities must keep pace with the times, constantly change the training mode of business English talents, and attach importance to the cultivation of students' practical application, innovation and entrepreneurship, so that it will constantly improve and strengthen the core competitiveness of students in the field of foreign trade.

\section{Development Of Internet And Business English}

\subsection{The Basic Concept of the Internet}

The concept of "Internet" first appeared in 2012, mainly to integrate the Internet and other fields, through the application of Internet science and technology in other fields, to achieve the purpose of mutual integration and mutual development, and to promote the harmonious and orderly development of various industries. At the first World Internet Conference in 2014, Chinese Premier Li Keqiang proposed that the Internet is a new development model for mass entrepreneurship and innovation, and a new motive force and engine to promote the economic development and upgrading of our country. At the 2015 session of the National people's Congress, Prime Minister Li Keqiang put forward the "Internet" plan for the first time in his government work report, combining advanced science and technology such as the Internet, big data, cloud platform and modern manufacturing industry to jointly promote the healthy and orderly development of the Internet and various industries, and jointly open up and develop the international trade market [1].

\subsection{The Basic Characteristics of the Internet}

The Internet has seven main features:

1) Cross-industry integration: as the name implies, cross-industry integration is reform, development, through the combined development of different industries, the Internet technology will be brought into various industries, promote the integration of innovation in various industries, and transform consumption into investment. From technology research and development to industrialization process, all need the integration of network technology.

2) Innovation drive: the early economic development of our country is mainly developed through extensive and labor-intensive economic growth mode. With the progress of the times, the current economic development model must focus on the track of innovation-driven development through the Internet science and technology to change, develop, stimulate the innovation energy in the field of industry.

3) Replacement structure: with the development and progress of economic globalization and the popularization of the Internet, the development structure, cultural structure, economic structure and other structural contents of society are undergoing great changes. Internet technology will integrate and innovate the changed social structure and create a new structural model in line with social development and people's lives.

*Corresponding author's e-mail: 739960103@qq.com 
4) Respect for human nature: the development of Internet technology can not be separated from human research and exploration, the innovation and development of technology is ultimately to serve human beings, the development of human nature is to promote social progress, scientific and technological progress, economic improvement, cultural development, etc. The emergence of the Internet is also the greatest respect for human nature and development attention.

5) Rule of law economy: the research and development of Internet technology are carried out within the framework of the rule of law. The development of the rule of law pays more attention to the protection of intellectual property rights and innovation of the Internet, and strengthens people's legal consciousness on the Internet[2].

6) Ecological opening: through the development of the Internet, people push the development of ecological civilization to a new climax, innovate the open ecological development model, and embody the development value of important ecological innovation.

7) Contact all: the promotion of Internet technology, the development of the whole society linked together, produced a huge social and cultural value, to achieve the great development goals.

\subsection{The Development of Business English in the Context of Internet}

At present, business English is still mainly on the level of classroom theory teaching. Most colleges and universities lack the cultivation of innovative and entrepreneurial ability. The main purpose of teaching is to combine English culture with business related knowledge. Some teachers and students think that their success rate of innovation and entrepreneurship is low. The so-called innovative entrepreneurship education has become a simple form of classroom teaching. There is no deep integration of the business professional knowledge and English related knowledge, To carry out some innovative entrepreneurial ideas and research.

Business English professional education is relatively single, lack of innovative and entrepreneurial all-around teachers, mainly because business English is the content of business knowledge and English knowledge, under the content of business English to develop innovative entrepreneurial ability, need solid, rich business practice knowledge and skilled English skills knowledge, this is the teaching basis for innovative entrepreneurship, most college business English teachers have a lot of English teaching experience, but there are few teachers with rich business practice ability or business management experience, which results in the classroom teaching of business English, Teachers and students can not share and teach vividly about business operation, operation and other related practical knowledge, lack of innovation and entrepreneurship in teaching practice, regard the so-called business English innovation and entrepreneurship as classroom lectures on paper, and do not change the traditional classroom teaching mode.

Therefore, business English teaching essentially spans the professional fields of business and English, and in order to develop innovative entrepreneurship education in business English, It is necessary to absorb and cultivate teachers with both cultural theory knowledge of daily English and rich experience in business practice[3]. At present, a considerable number of teachers majoring in business English in colleges and universities in China have a deep level of English theory teaching, but generally lack rich business negotiation, management, marketing and other business practice knowledge, lack of business related information, materials, data and other content with the forefront of the times.

\section{Development The Cultivation of Innovative Entrepreneurship Ability Of Business English In The Context Of Internet}

The new era will have new development ideas and new development models, as in business English education. Under the background of the "Internet" era, the development concept and development mode of college education should speed up the pace of innovation, especially in business English teaching, we should make full use of new scientific and technological means such as the Internet.

Innovative ideas for business English courses in the context of the Internet, as shown below: 


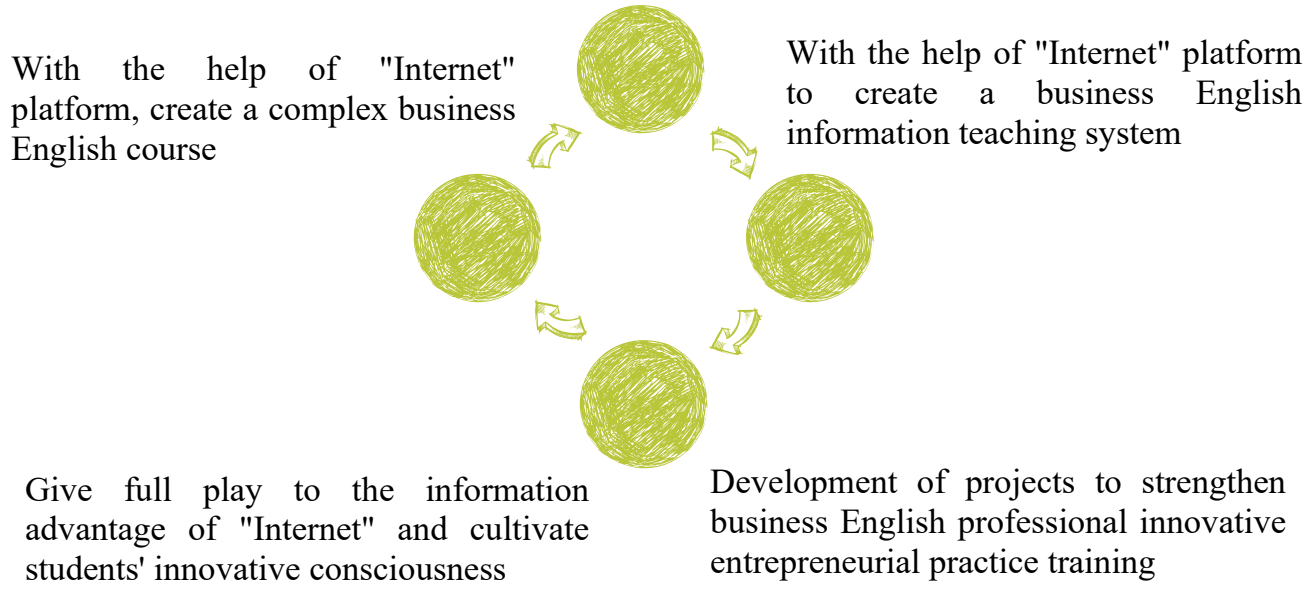

Figure 1. Innovative Ideas of Business English Curriculum in the Context of Internet

\subsection{Innovating teaching mode and improving teaching innovation ability}

In the past English teaching methods, the emphasis is on the proficiency in English language expression ability and grammar ability, cultural knowledge and so on. When the students really go to work after graduation, they find that the practical ability is insufficient, and the students' innovative and entrepreneurial ability is poor, so it is difficult to adapt to the development needs of the times. Therefore, today's colleges and universities should study more diversified teaching and training contents, and carry out diversified integration and development of business and English At the same time, we should make full use of the geographical and environmental advantages of colleges and universities, strengthen the teaching and training cooperation between universities and local leading enterprises, establish practical teaching bases for business English, teach students according to their aptitude, and analyze specific problems. At the same time, colleges and universities should adopt the technical means of relying on the Internet to construct the online brand course of business English through the combination of "Internet" and teaching mode[4]. Students are free to choose targeted business English extension courses according to their interests and development goals, improve their innovative entrepreneurial ability, and enable students to participate in diversified extracurricular teaching activities outside the traditional classroom.

\subsection{To create a learning atmosphere of innovation and entrepreneurship on campus and cultivate the innovative consciousness of learning}

In order to fully stimulate the innovative entrepreneurial ability of college students in business English class and promote more business English students to participate in innovative entrepreneurial activities, foreign language colleges in colleges and universities continue to cooperate with other colleges on campus. Build campus innovation awareness culture platform, create a strong innovation campus culture atmosphere, in the students subconscious cultivation of innovative entrepreneurial development concept. Hold campus innovation and entrepreneurship skills competition, set up a variety of awards, encourage more learning to join in. Colleges and universities can also through the campus website, WeChat public number, broadcast, publicity bar and other ways to promote innovation and entrepreneurship. Invite business English industry leaders to give lectures and lectures on innovative entrepreneurial ideas, improve students' interest and ability in learning, create a new platform for students to innovate and develop business English, invite outstanding alumni and successful entrepreneurs to guide innovative methods on the spot, teach entrepreneurial heart and experience, and carry out academic exchanges and discussions. Let students get the most direct feelings, set up students in the social wave dare to break, dare to fight, dare to think of value orientation and outlook on life, through professional teachers for practical guidance, for students to create more practical opportunities, so that students deeply grasp the correct ways and means of innovation and entrepreneurship.

\subsection{Strengthen the investment of innovative venture capital and establish a practical platform for innovation and entrepreneurship}

From the current business English development model and the form of demand for talents, today's information construction requires business English professionals to obtain more social resources and opportunities in social employment. Therefore, colleges and universities should 
increase the investment of funds in the cultivation of innovative entrepreneurial ability of business English talents, tilt the annual education budget to business English education, and establish and perfect the construction of business English innovation and entrepreneurship practice platform. Actively develop business English innovative entrepreneurial skills training, build business English practice training center and innovative entrepreneurial practice base, constantly strive for relevant positions for students to practice, build a rich and diversified business English practice system and educational content, Expand the space direction of innovation and entrepreneurship, and provide reliable guarantee for the cultivation of innovative entrepreneurial ability of business English. To actively develop and guide students to participate in the practice of innovation and entrepreneurship, to provide certain financial support to outstanding students who have received practical training and competition awards, to help students complete relevant project design, to focus on building and supporting, to thoroughly enable students to fully and effectively combine theoretical knowledge with practical ability[5].

\section{CONCLUSION}

In the new era of public entrepreneurship and innovation, the teaching methods of business English majors should be explored in all directions. Colleges and universities should rely on strong Internet science and technology to develop innovation-driven ability, and put forward higher development goals for the cultivation of business English majors in colleges and universities in China. In the future, business English majors should pay more attention to the cultivation of their own innovative entrepreneurial ability and constantly improve the position of business English in social development.

\section{Acknowledgement}

JXJG-19-55-8 Research on the cultivation of innovtion and entrepreneurship under the OBE teaching mode.

\section{REFERENCES}

1. General Office of the State Council of the People's Republic of China.(2015)General Office of the State Council Opinions on the Implementation of the Reform of Entrepreneurship Education [J].Employment of Chinese University Students.

2. Wu,Y.T.(2020)Competition Training System and Cultivation of College Students'Innovation and Entrepreneurship — Taking the Practice Exploration of Guangdong as the example[J].

3. Wang,S.L.(2018)Training Strategy of English Talents for Cross-border E-commerce in Fujian under Internet[J].Journal of Suzhou Institute of Education.

4. Li,Y.(2018)On the Construction of Business English Major Course in Higher Vocational College Based on the Internet[J].Journal of Hubei Correspondence University.

5. Di,C.J.Qiang,M.Wang,Z.L.(2016)Research on the Training Mode of Innovative Entrepreneurial Talents in Higher Education Based on Internet[J].Journal of Chongqing Institute of Science and Technology: Social Sciences Edition. 